\title{
Isolation and identification Staphylococcus aureus from Cows ruminal content
}

\author{
Hanaa Khlil Ibrahim \\ Department of microbiology - College of Veterinary Medicine - University of Basrah
}

\begin{abstract}
$\underline{\text { Abstract }}$
This study was carried out for isolation of Staphylococcus aureus and identification it from Cow's ruminal contant through take of specimens and caltured it on (MSA), the percentage of isolation on this media about 52\%, Biochemical tests were done. In biotyping test the percentage reveled in type $\mathrm{C}$ about $61.5 \%$ while in type A $38.4 \%$. The specimens gave $76 \%$ for pigment on Milk agar.While in antibiotic tests appeard sensitive $80.76 \%$.
\end{abstract}

\section{$\underline{\text { Introduction }}$}

Simple stomached animal (e.g.pig, chickens, rats and man) lack enzyme that can degrade cellulose or hemicelluloses, and fibrous materials are poorly utilized. Ruminant animal (e.g. cattle, sheep, goats, dare.Etc.) do not synthesis fiber digesting enzyme, but they have formed a symbiotic relation ship with ruminal micro organisms that can. The ruminant provides the micro organisms with habitat for their growth, the rumen and microorganisms supply the animal with fermentation acids, microbial protein and vitamins (1).

Ruminant nutritionists have long been interested in modulating the competition among different microbial populations with the objective of improving the efficiency of energy and protein utilization in the rumen. This has been achieved through the optimization of diet formulation and the utilization of feed additives that modify the environment and enhance or inhibit specific microbial population (2).

Some ruminal bacterial produce lactic acid at a rapid rate, and this acid can cause pronounced declines in ruminate $\mathrm{PH}$, founder, and in sever cases, even death of the animal (3).

The predominant rumen bacterial species occurring in cattle,sheep metabolism in the goat are to be interpreted as similar to the values in cattle and sheep.(4)

Staphylococci display high virulence, other may have acommensal relation ship with their host, staphylococci Forman important component of the bacterial community in the rumen content as well 
as on the rumen wall of domestic and wild ruminants. $(5,6)$.

Despite the fact that staphylococci are known also lactic acid producers and belong together with lactobacilli and interococci to the first bacterial group colonizing the rumen of young ruminants (7), they may be important in causing infection under the appropriate prides posing conditions similar to those described by (8) for enterococci.

The aim of this study is isolation and identification of Staphylococcus aureus from ruminal content of cows .

\section{Material and methods}

Samples collection: A total of 50 samples were randomly collected from cows ruminant content in order to isolate Staphylococcus aureus.

Laboratory diagnosis: The specimens were transported to the laboratory directly. In the laboratory the diagnosis was performed by :

\section{A- Culturing :}

The specimens were directly inoculated on a plates of Mannitol Salat Agar (MSA) and incubated at $37^{\circ} \mathrm{c}$ for $24 \mathrm{hrs}$. All colonies from primary cultures were purified by sub culture on (MSA) medium and incubated at $37^{\circ} \mathrm{c}$ for $24-48$ hrs.(9)

\section{B-Microscopic examination :}

Asmear was prepared and staind with Gram stain. to see $\mathrm{G}+$ cocci in cluster(10)

\section{Biochemical test:}

A. Catalase test : a small amount of pure growth was transferred with a wooden stick from mannitol salt agar to clean slid, then a drop of Catalase reagent was added(hydrogen peroxide. $3 \%$.The evaluation of gas bubbles indicates a positive test (11)

B. Coagulase test: This test was done according to (12) by adding $0.1 \mathrm{ml}$ from 18 $24 \mathrm{hrs}$. Culture broth to the $0.1 \mathrm{ml}$ of human plasma without dilution and incubation at $37^{\circ} \mathrm{c}$ for $4 \mathrm{hrs}$. the appearance of the clotting indicates a positive result comparable to control.

\section{Biotyping test:}

A. Haemolysin production:All bacterial isolates were streaked on blood agar and incubated at $37^{\circ} \mathrm{c}$ for $24 \mathrm{hrs}$. Presence of zone of haemolysis around the colonies was considered as appositive tesult (13)

B.Growon Crystal violate medium: This medium was prepared by adding $0.1 \mathrm{ml}$ of crystal violet to brain heart agar to 1 liter D.W.(1:10 000). (14).

C.Pigment production on Milk agar: This media was prepared by dissolve nutrient agar $28 \mathrm{gm}$, in $700 \mathrm{ml} \mathrm{D.W}$. and autoclaving , after that cooling to $55^{\circ}$ and supplement with $300 \mathrm{ml}$ of milk and distributed in petri dishes, It was based on method by Christi and Keogh, 1945 and described by (10). It is used to test of pigment production.

\section{Biotyping:}

The isolates of S.aureus were cultured on the Milk Agar and incubated at $37^{\circ} \mathrm{C}$ for 24hrs. The appearance of yellow pigment was indicated as appositive results. Depending on the results to Coagulase production, culturing of isolates on the crystal violate medium different biotypes of four classified depending on the color of the colonies on this medium,biotype A appeared in acrystal violate color, biotype B appeared white on, biotype $\mathrm{C}$ appear yellow while biotype $\mathrm{D}$ did not grow on this medium.(14)

\section{Antibiiotic susceptibility Test:}

This test was done according to method of (15). pure colony transferred to clean tube contain $4 \mathrm{ml}$ Brain Heart infusion broth and incubated at $37^{\circ} \mathrm{c}$. After moisten the swab in the broth culture and the swab was passed on the surface of the MullerHinton agar from center to the border, the 
plate was left for $15 \mathrm{~min}$. to be dry, the discs of antibiotics were fixed on the plate by using sterile forceps, after incubation at $37^{\circ} \mathrm{c}$ for $24 \mathrm{hrs}$. The inhibition zone was measured and compared to special standard table containing.

\section{Results:}

The results showed that $26 / 50(52 \%)$ of Cows rumen content gave positive result (able to grow) on mannital salt agar (MSA) after $24 \mathrm{hrs}$. the suspected colonies of $S$. aureus were, round, smooth, raised, glistening, gray to deep golden yellow in color, the smear of suspected colonies showed Grape like cluster G+ cocci. The result of biochemical and growth tests revealed that all detected isolates were S.aureus (100\%).

Table showed that $69.23 \%$ of isolates were B- hemolytic and $61.5 \%$ isolates were C biotype, while the pigment production on milk agar was observed in $76.92 \%$ of isolates.

\begin{tabular}{|c|c|c|c|}
\hline \multicolumn{4}{|c||}{ Table (1): Number \& percentage of S.aureus biotypes } \\
\hline BIOTYPING TEST & NO. OF BIOTYPE & PERCENTAGE & TOTAL \\
\hline Beta- Heamolysin & 18 & $69.23 \%$ & 26 \\
Alfa- Heamolysin & 8 & $30.76 \%$ & 26 \\
\hline Biotype C & 16 & $61.5 \%$ & \\
Biotype A & 10 & $38.4 \%$ & 26 \\
\hline Pigment & 20 & $76.92 \%$ & \\
\hline
\end{tabular}

Table (2) display the susptibility of S.aureus isolates against (10) antibiotics. Mast isolates showed higher susptibility rate to
Ciproflaxcin $80.76 \%$ and all tstes isolated showed higher rate of antibiotic resistance 96.15\% against the Metronidazol.

Table (2) : The antibiotic sensitivity test results

\begin{tabular}{||c|c|c||}
\hline ANTIBIO TIC & $\begin{array}{c}\text { SENSITIVE } \\
\text { ISOLATS }\end{array}$ & $\begin{array}{c}\text { RESIST ANCE } \\
\text { ISOLATS }\end{array}$ \\
\hline Ttobramycin & $18(69.23 \%)$ & $5(19.23 \%)$ \\
\hline Chloramphenico1 & $20(76.92)$ & $4(15.38 \%)$ \\
\hline Enrofloxacin & $9(34.61 \%)$ & $12(46.15 \%)$ \\
\hline Vancomycin & $10(38.46 \%)$ & $14(53.84 \%)$ \\
\hline Gentamicin & $20(76.92 \%)$ & $0(0 \%)$ \\
\hline Erythromycin & $5(19.23 \%)$ & $15(57.69 \%)$ \\
\hline Ciprofloxacin & $21(80.76 \%)$ & $3(11.53 \%)$ \\
\hline Penicilin & $4(15.38 \%)$ & $21(80.76 \%)$ \\
\hline Metrondazol & $0(0 \%)$ & $26(100 \%)$ \\
\hline Kanamycin & $17(65.38 \%)$ & $5(19.23 \%)$ \\
\hline
\end{tabular}




\section{Discussion:}

The rumen is inhabited by bacteria , protozoa and fungi, but bacteria play a dominant role in all facts of ruminal fermentation (16) Gram- Positive bacteria produce more ammonia, hydrogen and lactate then Gram- Negative species, and compounds that inhibit Gram-Positive ruminal bacteria have increased feed efficiency (17)

The present study aimed to detect or investigate the presence of S.aureus in 50 samples of rumen. S.aureus was diagnosed in an over all rate $(52 \%)$.

The presence of this bacteria in Basrah was supported by study conducted previously in Basra by Basim,(2009) who reported this microorganism was isolated from bovine in percentage $63.36 \%$.

According to production of Pigmen ,Heamolys ,Coagulase of bovine plasma and growth on crystal violate, S.aureus was classified in present study in to biotype $\mathrm{C}$ $61.5 \%$ and biotype A $38.4 \%$.This result was in line with the findingof Hanon(18) who reported the biotype which is specific to bovine isolates with percentage $83.33 \%$ and biotype A which specific to human in $16.66 \%$ of isolates .

Also these result was agreement with (19) who, mentioned that the majority of S.aureus isolates from ewe milk and cheese were found to be bovine biotype $62 \%$ Bendahou et,al.(20) showed that the four biotype A,B,C, unspecific, S.aureus isolates of milk and milk products appeared bovine origin , biotype $\mathrm{C}$ with the percentage $45 \%$ and more dominant then other biotypes.

The present results showed the ability of S.aureus isolates to produce Betahaemolysis $69.23 \%$, these result was in line with finding of (21), who reported that the percentage of B- haemolysin production were $84.9 \%$ in bovine isolates . while this results were in compatible with the results of
(22), who found the percentage of Bhaemolycin in ovine $82.25 \%$, cows $72.7 \%$ and equine $72 \%$ with total percentage $78.2 \%$ but the study disagreed with (23) found isolates from clinical and sub clinical mastitis in cows produce Alfa - haemolysis in $89.79 \%$.

This study revealed different percentage of susceptibility to different antibiotic and showed that $80.76 \%, 76.92 \%, 76.92 \%$, $69.23 \%, 65.38 \%$ of S.aureus isolates were sensitive to Ciprofloaxicin, Choralphenical, Gentamycin, Tobramycin and Kanamycin respecitivily. This result was agreement with (23) who reported that S.aureus isolated from bovine were highly sensitive to Gentamycin $70.37 \%$, Streptomycin $64.63 \%$, Erythromycin 50\%,chloramphenical $43.9 \%$ and had high resistance to Penicillin $96.13 \%$ .In the study of (24) recorded that S.aureus isolated from mastitis cows appeared to be highly sensitive for Ciprofloxacin ,Chloramphenical and Gentamycin.

High resistance appeared to Penicilin and Cloxacillin. But the study of (25) recorded high sensitivity of S.aureus isolates from Mastitis to Ciprofloxacin 100\%, Gentamycin $76.8 \%$ and Chloramphenical $41.04 \%$. The high percentage of rssistance appeared to Penicilin $98.27 \%$, and all strain showed resistance to Vancomycin Bendahou et,al. (20) mentioned that S.aureus isolated from raw milk and milk product appeared sensitive to Vancomycin $100 \%$ Chloramphenical 90\%, Erythromycin $80 \%$, and high resistance to pencilin (22). AlRahman (26) found the high susceptibility to Gentamycin 100\%, Tobramycin 90\%, Chloramphenical $88 \%$ Erythromycin $76 \%$ and less sensitive for Penicilin 26\% in isolates from Camel.

\section{References}

1.Hungate , R.E. (1966). The Rumen and Its Microbes. Academic press, New York. Iverson , W.G., and Mills , N.F. 1976 
.Bacteriocins of streptococcus bovis. Can .J. Microbial .22:1040 - 1047.

2.Calsamiglia , S.,L.; Castillejos, L and Busquet, M.. (2006). Alternatives to antimicrobial growth promoters in cattale .Pages 129167 in Recent Advances in Animal Nutrition .P.C..Gransworthy , and .J.Wiseman, ed. Nottingham University Press, Notting ham, UK.

3.Owens, F.N.; Secrist , D.S.; Hill, W.J. and GILL, D.R. (1998). Acidosis in cattle : Areview J.Anim Sci .76: 275 - 286.

4.Dehority, B.A. and Grubb, J.A. (1977). Characterization of the Predominant Bacteria Occurring in the Rumen of Goats (Capra hircus).American Socity for Microbiology . 33(5): 1030 - 1036.

5.Fonty, G.; Jouany, J.P.; Senaud, J; Gonte, P. and Grain; J. (1984). The evolution of microflora, microfouna and digestion in the rumen of Lambs from birth to 4 months. Can .J. Anim Sci;4(Suppl): 165 166.

6.Kmet, V.; Baran, M. and Kalachnyork , G. (1990). Influence of ruminal ecosystem of Calves and lambs by microbial preparation (in Slovak) .Ed: veda, PP. 511

7.Laukova', A. (1994) : Staphylococci associated with the rumen of young and wild ruminants . Lett Appl Microbiol , 19: 26- 27.

8.Jett, B.D.; Huycke, M.M. and Gilmore, M.S. ( 1994) : virulence of enterococci . Clin Microbial Rev; 7 : 462- 478.

9.Talan , D.A.; Staatz , D.; Staatz A.; Goldstein; E.J.C.; Singer, K. and Ocrturf, G.D. (1989). Staphylococcus intermidius in Canine gingival and Canine - infected human wound infections : Laboraory characterization of newly recognized Zoonotic pathogen .J. Clin. Microbiol ;. 27: 78- 81.

10.Cowan, S.T. (1986). Manual for the identification of medical bacteria $.2^{\text {nd }} E d$. Cambridge University press Cambridge, London, New York.

11.Finegold, S.M. and Baron, E.J. (1986). Methods for testing antimicrobial effectiveness in Baily and Scott's diagnostic microbiology $.7^{\text {th }}$ Ed. The C.V.Mosby Co. west line . Industrial Drive, ST, Louis , Missuri, USA.

12. Treagan ,L. and Pulliam, L. (1982). Medical microbiology procedures, W.B.S aunders Co.

13.Macfaddin, J.F.(2000).Biochemical test for identification of medical bacteria .3th Ed.

14.Cohen , G.E.(1982). Veterinary Microbiology. Edit .La prensa medica Mexicano, mexico.

15.Green , D.; Slack, R.C. and Peutherer, J.F. (2000). Medical Microbiology . A guide to Microbial infections: Pathogenesis, immunity . Laboratory diagnosis and control. Churchill.Livingstone. $2^{\text {nd }}$ edition. p.p $=46-54$.

16. Russell, J.B. and Mantovan, H.C.(2002). The Bacteriocins of Ruminal Bacteria and Their Potential as an Alternative to Antibiotics.

17.Russell, J.B., and Strobel, H.J. (1989). MiniReview: the effect of ionophorse on ruminal fermentation .Appl.Environ. Microbiol , 55: 1-6.

18.Hanon, B.M.(2009). Comparative study to the Staphylococcus aureus isolation from bovine and human with the detection of virulence (Coa) gene byPolymerase Chin Reaction (RPC). M.Sc., Thesis, College of veterinary Medicin, University of Basra.

19.Lamperll, L.; Villard , L.; Chamba, F.; Bewier, C ; Borges, E. Maurin,F.; Mazerolles G.; Noel , Y. and Kodja, A. (2004). Identification and biotyping of coagulase positive Staphylococci (CPS) in ripened French raw milk cheeses and their in vitro ability to produce enterotoxins. Revue. Med. Vet. 155(2) : 92- 96.

20.Bendahou, A.; Lebbadi, C. ;Ennanei ,L.; Essadqzui , Z. and Abid, M.(2008). Characterization of Staphylococcus Species isolated from raw milk and milkproducts (Iben and jben) in North Morocco . J. Infect . Developing Countries , 2(3): 218- 225.

21.Sale, A.H.(1990). Some side Staphylococcus aureus isolation from human and diffrernt animal .M.Sc. Thesis, College of 
Veterinary Medicine, University of Bagdad. (In Arabic).

22.Ismiale , B.M. (1986). Systems for phage typing of Staphylococcus aureus of animal origin .M.Sc.Thesis collage of veterinary Medicine . University of Bagdad.(In Arabic).

23.Mustafa, J.Y.(2007). Isolation and diagnostic some causative agent of bovine Mastitis , with extraction and purification of Staphylococcus aureus B-Lactamase .M.Sc. Thesis, College of Veterinary Medicine ,Universitybof Basra .(In Arabic).

24.AL- Kafaji ,N.A.(2008) .Experimental study for the effect of Plantago lanceolata and Eugenia caryophyllus extract in the growth and pathogensis of Staphylococcus aureus in Laboratory animal . M.Sc. Thesis, College of Veterinary Medicin of Bagdad .(In Arabic).

25.AL. Marsomy ,H.M.(2008). Isolation and diagnostic some causative bacterial, causes of Mastitis in Cows and role Lactobacillus secretion at inhibition growth of Staphylococcus aureus .M.Sc.Thesis, College of Veterinary Medicin , University of Bagdad .(In Arabic).

26.Abd- AL- Rahman, A.M.(1989). Staphylococcus aureus isolation from Camel .M.Sc. Thesis, College of Veterinary Medicine, University of Bagdad.(In Arabic).
عزل وتشخيص المكور ات العنقودية الذهبية من محتويات كرش الأبقار

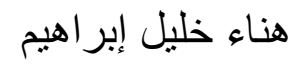

جامعة البصرة ـ كلية الطب البيطري - قسم الاحياء المجهرية

أجريت هذه الدراسة لعزل المكورات العنقودية الذهبية وتتخيصها من محتويات كرش الأبقار من خلال اخذ عينات

وزرعها على أكار المانيتول الملحي وسط (MAS) وقد كانت نسبة العزل به\% أجريت بعض الاختبارات الكيموحيوية

التي أكدت كون العزلات مكورات عنقودية ذهبية وكانت نسبتها . . 1\% ، أجريت الاختبارات biotyping حيث كانت من

نوع C1,5 C أما نوع A 38,4 وأعطت نسبة 76\% للاختبار الصبغات على وسط الحليب. أما بالنسبة للاختبارات

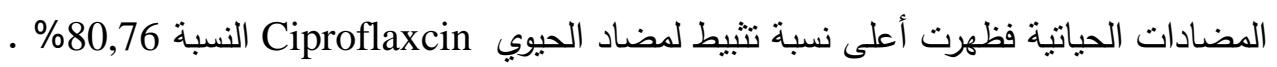

